\title{
Morphology Systematic and Evolution: A Review of Indian Phlebotomus Phlebotomies (Diptera: Psychodidae) with a Description of One New Species
}

\author{
Prakash Ramu Salunke \\ Department of Indian Council of Medical Research Ansari Nagar, New Delhi (National Institute of Virology) Pune, India
}

Copyright $\subset 2017$ by authors, all rights reserved. Authors agree that this article remains permanently open access under the terms of the Creative Commons Attribution License 4.0 International License

\begin{abstract}
The objective of this study was to carry out a taxonomic of Indian phlebotomine sand flies and describe one new species found in human dwelling in the villages of vaseti district panchmal gujarat state India, The gonostyle of one of these, gujarat vasetinov. sp., species group as waldio, has five spines sperm theca uicinikshepd segments, similar to that of phlebotomine papatasi Biobio 1876 Hewlett 1915 Phlebotomine subgenus Romani and Bertie 1840; Theodor, 1948: Lewis, 1965[6], species group as waldio, but they may be distinguished by the alpha /gamma ratio, which is $<1,0$ in the new species, which distinguishes it from the other phlebotomie species, With the description of these one new species of the Indian phlebotomie sand flies has been described, 5 of which belong to the subgenus Gujarat vaseti An identification key for male female species is presented.
\end{abstract}

\section{Keywords Phlebotominae Gujarat vasetinov. sp, Human Dwelling}

\section{Introduction}

The only three species of phlebotomies were known in the world in 1905 when impetus was given to their study by their suspected association with sand fly fever andleishmaniosis. By 1925, 47 more species were known, 14 of from the Orient, including nine from India and two from Sri Lanka. In1926 Adler and Theodor discovered the taxonomic value of cibarial teeth and sperm thecae, giving further impetus to sand flies taxonomy,Devastating epidemics of kala-azar, discussed in a later section, had led to intensive research during which J. A. Sinton published a long series ofimportant taxonomic papers mainly on India and Pakistan, from 1921 to 1933, Renal and Gosheninvestigated lands- Chinese species, a few other workers studied some Oriental species, and uniterecently madeimportant contributions from south-east Asia to stimulate research. The subfamily phlebotomies constitutes a group of insects of importance topublic health because several of insects species arevectors of, viruses, bacteria and especially Leishmamia, protozoan's implicated as the etiologcagents of leishmaniosisthroughout the world, thus motivating biological, ecological, and systematic studies of its viruses species, because several of insects species are vectors of bacteria, viruses and especially Leis Mania, protozoan's implicated as etiological agents of motivating biological, and systematic as of its various species. The sub-family phlebotomies has a worldwide distribution mainly intropics argentipes are the known vectors of theSand fly fever viruses and leishmaniosis argentipes are the known vectors of the Sand fly fever viruses and leishmaniosis respectively (Karabatsos 1985)[5].

\section{Corresponding Author: Prakash Ramu Salunkhe}

A- 201 Surobhi Regency Ghorpadi B. T. Kawade Rood Pune,411001, Maharashtra, The following visceral leishmaniosis, this disease, known askala-azar, is caused by Le.Donovan (Laveran and Mensal, 1903), and India is one of the few countries with no known animal reservoir, though Adler (1964)[1] believed that the disease might have developed from a zoonosis and he and Garnham (1965)'and Hoare (1955) thought that the infection might still be found in a wild animal. The name kala-azars, meaning black fevers, came fromthe Gyro Hills in India, where it referred to the appearance of victims. Before treatments was discovered, about 75 per cent of patients died, mostly within two years. Sen.Gupta (1968)[10] reported a death rate of 90-95 percent amonginfected people and a general mortality of over 25 percent in some districts. The terror of this once-deadly disease caused many people to desert their villages (Manson-Bahr, 1946), and its severity and tendency to spread led to enormous loss of lives, depopulation and failure of agriculture(Sen.Gupta, 1967). Several epidemics occurred 
in Bengal and were confused withmalaria till treatment failed to prevent many deaths. Kala-ajar attracted special attention when it began to in videsAssam in1875 with the development of communications (Sen.Gupta, 1967 between then and 1917 it swept up the Brahmaputra valleys in three distinct epidemic waves.There were epidemic periods of about ten years and inter-epidemicperiods of about ten years and inter -epidemic periods of 15-20 years (Shortt, 1945).Before 1946 thedisease was known to be widely distributed in India but theepidemic areas werewell defined(Napier, 1926:) Infections occurred near Cape Cormorin and in Madras,and from there the coast was free till the Ganges delta. The plains Bengal were heavilyinfected endemic area and the extended along Ganges plaininto Bihar and to the easternside of Uttar Pradesh as for as Lucknow, to the north-east, Assam was heavily infected, as for as Sibsagar. Sopoli Papatasi[9]. The following general summary is basedon the work of Tosh and Chariots (1975), Tosh. (1975)[13] and other authors mentioned below, Sand filly-borne viruses of vertebrates may have evolved from arthropod viruses, and belong to three distinct serogroups, vesicular steatites, Phlebotominae+ fever and (American), Changuinola. TheFollowing temperate climates some species of sand flies emerge fromwinter diapauses and pass-through one or two annual generations which determine theirseasonal incidences. In the tropicsseasonal occurrence seems to dependon specific biology and local conditions. Some species occur through out the year. Some flourish inthe dry seasons when breeding places are not flooded. Others are numerous in the rains, when high humidity may favor the adults and larvae of woodland species. Existing knowledge ofseasonal changes in the Orient is summarized below, and seems to reflectthe gradual transitions from temperate to tropical conditions. In Lahore, Pakistan, Nassir(1958)[7] found sand flies from February to November, and George (1970) noted a sharpdecline in October and November. Dhandas[2] and Mode $(1971: 1567,1569)$ pointed out that in Pakistan sand flies tend to vanish in winter and to appear in March and become numerousin in April and in the damp month of August, whereas in peninsular Indiathey persist in the midwinter in Aurangabad (Deccan) and Poona districts; around Aurangabad sand flies were abundant throughout most of the year, and were most numerouswhen the moons diminished in December. At Pusa, in BiharState, Hewlett (1909)[4] noted that sand flies were common in late September and early October. Smith (1959)[] reportedthat in north-east India sand flies might vanish in thewinter in December and January, and diminish again in midsummer, being numerous after the monsoon, from August to October; in south India numbers were the lowest in hot dry months. Indo - China sand flies were rare in the colder part of the winter from January to March (Renal, 1936), and at Phnom Penh in Cambodia various species seemed to disappear in winter (Parrot andClassier, 1952 Around Pusa Hewlett (1915) observed that larvae of Phlebotominepapatasi which hatched at the start of the cold weather pupated in late February or earlyMarch according to temperature, and Craighead and
Das (1928) reported that the species increased somewhat in the rains in northern Bengal it was common in April (Brunetti, 1920). In Poona district Phlebotomize papatasi was common throughout the year (Metra, 1956), and in Bombay City, they seemed to diminish in the rains (Young, 1927)[14]. Metra(1959) reported Phletomus sergeant from March to October in Punch and Raise, Sinton(1924)[11] encountered sand flies in. In Indo - Pakistan October in Punch and Raise, Sinton (1924) encountered sand flies in. In Indo - Pakistan in summer, mainly in the less hot period, and found Phlebotomine majorin the hills in summer

\section{Materials and Methods}

A specie of the Indian Phlebotomies was based on direct observation under the microscope of specimens deposited in the Phlebotomies collection of the National Institute of Virology, Information on the morphological Characteristics of the other species was obtained from the new species which was found in a PhlGujarat vaseti piece of containing the male heliotype and female paratype. Sand flies resting indoors in houses and cattle sheds, and outdoors, in tree-holes rodent burrows and termite-hill, were collected with an aspirator, hose resting in bottle-necktie- holes were driven out by inserting astick and were trapped in sweep-nets, A few collections were also made with sticky traps which consisted of white paper fixed on embroidery rings and smeared with castor oil. These sticky traps were hung in front of the windows and doors in the evening and removed the next morning for examination, the sticking to the paper were removedwith fine camel-hair brush, cleaned in acetone and preserved A few biting collections were done cattle sheds, dusk and early part of the night, the other species was found in Phlebotominae. papatasi,Phlebotomies argentines, and Sergentomyia species and Adult rating sites most sand flies are wild and shelter in natural sites such as holes in trees, rocks, soil anima burrows, and Holes in termite hills. The insects were examined underthe microscope and measured using an ocular micrometer calibrated for this purpose, Drawings were made using the same microscope with the aid of a camera lucid photographs taken with Konica digital equipment with a definition of 8,0 megapixels, the photographs being taken directly through the eyepiece of the microscope of themeasurements are given in micrometers, Some morphological details that help todistinguish phlebotomiesfrom extant species have been provided, A dichotomous keyis provided to assist in the identification of the phlebotomies species.

\section{Results and Discussion Etymology}

The new pieces named after the Phl Gujarat vaseti from where both the heliotype and prototype were collected in the (2009) outbreak of encephalitis in stateof Gujarat vaseti 
Indian, and hence, the new species was named tocommemorate the event.

\section{Diagnosis}

The male ciboria teeth absent, pharyngeal teeth well developed oxide of with sub basal hairy process, antennal segments 3 and 4 papilla sacred hair, Style short with two terminals and three sub terminal Pointed and long pines. Adages with four lobes middle lobe broad andlong with thick tip of unique shaped paramours well developed two lobes. thick, genital pump well developed Female ciborium teeth absent, pharynx teeth present well developed and flies pale yellow color labrum with upper brush hairs well developed, antennal segments 3 and 4 papilla secondhair sperm theca common duct in the thick, walls carrots like sheep slightly well developed, locality and habitat-wise records for each species together, with general comments are given below; altitude of each locality is given against the name in parenthesis, $\mathrm{M}$ and $\mathrm{F}$.

\section{Results}

Family Psychodidae Newman, 1835

Subfamily Phlebotomies Kertesz, 1903

Representing the male and female respectively.

\section{Key to the Species of Phlebotomie Gujarat vaseti. nov, sp,}

Eye length $0.65 \mu \mathrm{m}, 20 \mathrm{x}$.

Pharynx length $153 \mu \mathrm{m}, 40 \mathrm{x}$.

Antennal Segment III $370 \mu \mathrm{m}, 40 \mathrm{x}$.

Antennal IV $159 \mu \mathrm{m}, 40 \mathrm{x}$.

Wing lengths $1.8 \mathrm{~mm}, 10 \mathrm{x}$.

Eye 0.67 length $20 \mathrm{x}$.

Pharynx length $229 \mu \mathrm{m}, 40 \mathrm{x}$.

Antennal Segment III $381 \mu \mathrm{m}, 40 \mathrm{x}$.

Wing length- $2.1 \mathrm{~mm}, 10 \mathrm{x}$.

In the male there are two, and sometimes three, spines on the surstyle, the bursal process of the paramour carries hairs only ventrally and is much longer than rest of the paramour, and the first two spines of the style are close together. The female pharyngeal teeth of the form a wide-meshed network, the proximal part of the sperm theca (near the ductless) has been variously described because its structure is difficult to see. Phl. Papatasi

Male labrum with upper brush hairs blade like, two median apical sensibly long, narrowand dorsal small. Hypo pharynx with about 18 teeth on each sideband 17 ventral teeth,and dental teeth clavatesensilla concentrated near middle of segment. Ciboria teeth absent. Pharyngeal teeth large well developed Oxide long, Style short with two terminals and three sub terminal Pointed and long with thick spines. Adages thick unique shapes, females Ciboria teeth absent. Pharyngeal teeth present well develop conical flask shaped sperm theca about 17 segment spindle-shaped common duct with finely wails long well developed, differsfrom other Species ----------------Phl. Gujarat vaseti

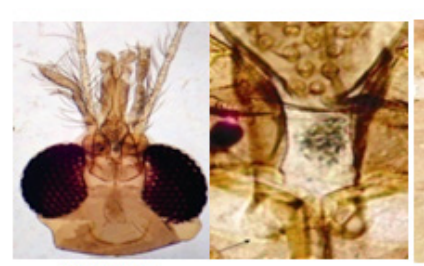

(A) Male

Ventral view of head 10

$\mathrm{xs}$,

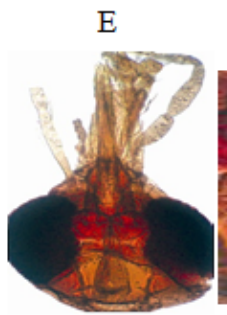

(E) Female,

Ventral view

of head 10

$\mathrm{x}$;
(B)

Ciborium 40x, Pharynx.40x, Terminalia.10x,

F



(F)

Ciborium and Pharynx.40x;
C

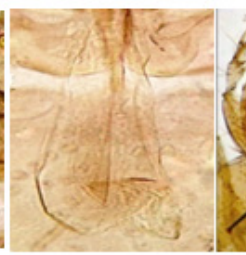

(C)
D

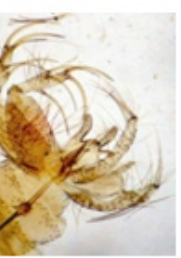

(D)


(n) 


\section{EGGS, LARVAE \& FOOD}

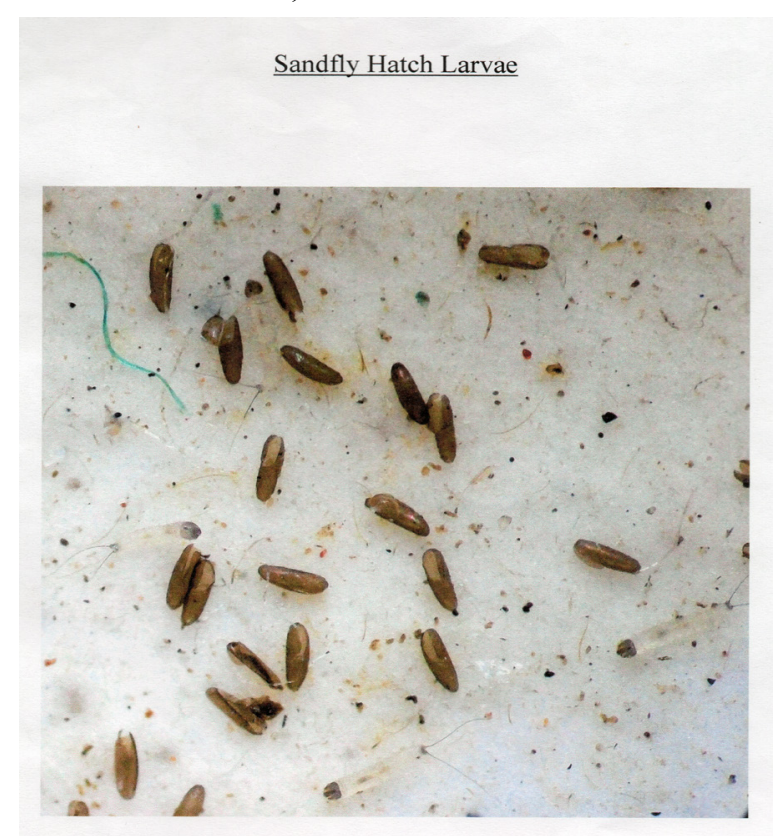

\section{REFERENCES}

[1] Adler, S, and O, Theodor, 1957, Transmission of disease agents by Phlebotominae sand flies, Annul. Rev, Entomolo. 2:203-226.

[2] Dhanda V, Rodriguez FM. and Gosh S N (1970).Isolation of Chandipura virus from sand flies in Aurangabad. India J Med es, 58: 179-180.

[3] Gee Varghese G, Arankalle AV, Judi R, Kanauji PC, Joshi MV and Mishra AC (2005). Detection of Chandipura Virus Sand Flies in the Genus Sergentomyia (Diptera: Psychodidae) in Karimnagar district, Andhra Pradesh, India. J Me Entomology, 42: 495-496.
[4] Hewlett, F. M. 1909. Indian sand-flies. Trans. Bombay med. Congr. 1909: 239-242. 1913. The natural host of Phlebotomus minutus. Indian J. med. Res. 1: 34-38., 1915, A preliminary note on the identification of sandflies. Bull. ent. Res. 6: 293-296.

[5] Karabatsos N (Ed) (1985), International catalogues of Arboviruses including Hygiene, San Antonio, Texas 78229, USA certain other viruses of vertebrates, American Society of Tropical Medicine.

[6] Lewis D J(1987) Phlebotomie sand flies (Diptera: 268 Psychodidae) from the Oriental region. Cyst Entomology. 12: 163-180.

[7] Nasir, S. 1958. Sandfly fauna in West Pakistan. Pakistan J. Hlth 8: 21-22. 1964. Sandflies as vectors of human disease in West Pakistan. Pakistan J, Hlth 14: 26-30.

[8] Rodriguez, F. M. \& Ghosh, S. N. 1970. Isolation of Chandipura virus from sandflies in Aurangabad. Indian J. med. Res. 58: 179-180.

[9] Scopoli, J. A; 1786. Deliciae faunae et florae insubricae. 1: 85 pp.

[10] Sen Gupta, P. C. 1947. Observations on an outbreak of kala-azar in Calcutta. Indian med. Gaz. 82: 726-734.

[11] Sinton, J, A. 1929. The identification and classification of the sices of Phlebotomus, with some remarks on their geographical distribution in relation to disease, Trans 7 th Cong, Far EastAssoc, Trop Med. 3: 172-193.

[12] Smith, R. O. A. 1926. A study of the bionomics of Phlebotomus argentipes, with special reference to the conditions in Calcutta. Indian med. Res. Mem. no. 4 : 161-172.

[13] Tosh R B, Modi G B, 1983. Growth and transovarial transmission of Chandipura virus (Rhadboviridae: Vesicnlovirus) in Phlebotomuspapatasi.Am J Trop Med Hyg32: 621623.

[14] Young DG Perkins PV. 1984 Phlebotomies sand flies of North America (Diptera: Psychodidae) Mosque. News 44; 263-285. 